\title{
Malignant transformation in a defined genetic background: proteome changes displayed by 2D-PAGE
}

Stephanie M Pütz ${ }^{1,2^{*}}$, Fotini Vogiatzi ${ }^{3}$, Thorsten Stiewe ${ }^{3}$, Albert Sickmann ${ }^{4}$

\begin{abstract}
Background: Cancer arises from normal cells through the stepwise accumulation of genetic alterations. Cancer development can be studied by direct genetic manipulation within experimental models of tumorigenesis. Thereby, confusion by the genetic heterogeneity of patients can be circumvented. Moreover, identification of the critical changes that convert a pre-malignant cell into a metastatic, therapy resistant tumor cell, however, is one necessary step to develop effective and selective anti-cancer drugs. Thus, for the current study a cell culture model for malignant transformation was used: Primary human fibroblasts of the BJ strain were sequentially transduced with retroviral vectors encoding the genes for hTERT (cell line BJ-T), simian virus 40 early region (SV40 ER, cell line BJ-TE) and H-Ras V12 (cell line BJ-TER).
\end{abstract}

Results: The stepwise malignant transformation of human fibroblasts was analyzed on the protein level by differential proteome analysis. We observed 39 regulated protein spots and therein identified 67 different proteins. The strongest change of spot patterns was detected due to integration of SV40 ER. Among the proteins being significantly regulated during the malignant transformation process well known proliferating cell nuclear antigen (PCNA) as well as the chaperones mitochondrial heat shock protein $75 \mathrm{kDa}$ (TRAP-1) and heat shock protein HSP90 were identified. Moreover, we find out, that TRAP-1 is already up-regulated by means of SV40 ER expression instead of H-Ras V12. Furthermore Peroxiredoxin-6 (PRDX6), Annexin A2 (p36), Plasminogen activator inhibitor 2 (PAl-2) and Keratin type II cytoskeletal 7 (CK-7) were identified to be regulated. For some protein candidates we confirmed our 2D-PAGE results by Western Blot.

Conclusion: These findings give further hints for intriguing interactions between the p16-RB pathway, the mitochondrial chaperone network and the cytoskeleton. In summary, using a cell culture model for malignant transformation analyzed with 2D-PAGE, proteome and cellular changes can be related to defined steps of tumorigenesis.

\section{Introduction}

The stepwise accumulation of genetic alterations in normal cells is estimated to be a major cause of cancer. One approach to study cancer development is direct genetic manipulation of primary cells to generate experimental models of tumorigenesis. Traditionally, murine cells or transgenic mouse models have been the primary targets of investigation and have provided crucial

\footnotetext{
*Correspondence: stephanie.puetz@uni-wuerzburg.de

1 Rudolf Virchow Center, DFG Research Center for Experimental Biomedicine, University of Würzburg, (Protein Mass Spectrometry and Functional Proteomics), D-97078 Würzburg, Germany

Full list of author information is available at the end of the article
}

insights into the molecular mechanisms underlying cancer development [1].

However, cancer biology of murine and human tissues clearly differs [2]. For example, primary human cells cannot be transformed with most combinations of oncogenes that readily induce transformation of primary rodent cells. In addition, prolonged culture of mouse embryonic fibroblasts (MEFs) results in their spontaneous immortalization, whereas comparable treatment of human fibroblasts leads to replicative senescence [2]. This phenomenon can be partially attributed to telomere biology: unlike murine embryonic fibroblasts,
C Biomed Central 
primary human fibroblasts have relatively short telomeres and lack detectable telomerase activity.

The majority of human tumor cells are telomerasepositive and expression of the catalytic subunit of the telomerase holoenzyme (hTERT) is sufficient to immortalize a variety of human primary cell types $[3,4]$. For example, SV40 LT transfected human fibroblasts have an extended lifetime but undergo crisis that can be rescued by expression of hTERT. Consistently, Hahn and co-workers succeeded to transform human primary fibroblasts and epithelial cells with the classical oncogenes $\mathrm{H}$-Ras V12 and the transforming early region of simian virus 40 (SV40 ER) following initial expression of hTERT in primary cells [5]. Subsequent work from many laboratories has confirmed the results and used the same combination of introduced genes to convert a wide variety of primary human cells to tumor cells, including human mammary epithelial, airway epithelial, glial, endothelial and mesothelial cells [6-10].

Whereas induction of hTERT and activating mutations of $\mathrm{H}$-Ras are frequently observed in human tumors, the small DNA tumor virus SV40 does not appear to be a common cause of human cancer. However, a dissection of the signaling pathways affected by SV40 ER has revealed striking similarities between SV40 ER function and alterations seen in human tumors [11]. The SV40 ER produces two major gene products, the large tumor antigen (LT) and the small tumor antigen (ST). LT is known to bind to and modulate the action of many host cell proteins, however, its role in the transformation of human cells appears to lie solely in the inactivation of the two major tumor suppressors, p53 and RB [11]. Consistently, specific siRNAs directed against RB and p53 can replace the requirement for LT in these experiments [12]. In contrast, ST, which inactivates the Serine/threonine-protein phosphatase (PP2A) via binding to the $A$ and $C$ subunits, exerts its oncogenic potential, at least partially, by preventing dephosphorylation of c-Myc, resulting in c-Myc stabilization [13-15]. Moreover, a stable c-MycT58A mutant that cannot be dephosphorylated by PP2A replaces SV40 ST in human cell transformation and tumorigenesis assays. Considering that c-Myc is one of the first identified oncogenes, it can be concluded that the transforming early region of SV40 appears to target the same cellular signaling pathways that are frequently affected during human tumorigenesis. In turn this renders the model of human cell transformation by the combination of the defined genetic elements hTERT, SV40 ER and H-Ras V12 an attractive model system to analyze changes during human cell transformation in molecular terms.

Progress in genomic and proteomic technologies (e.g. sensitive and fast MS and MS/MS analysis of proteins and peptides) promise to identify the characteristic signatures of specific cancer subtypes, to improve the classification of tumor types, and to identify prognostically relevant markers. However, these studies are always confounded by the genetic heterogeneity of patients. Thus, understanding the development of the transformed phenotype therefore requires analysis of the various stages of tumorigenesis in a defined genetic background. Whole-genome-scale technology then allows the identification of the molecular changes during each transition. As a first approach, we analyzed the stepwise transformation of human fibroblasts by a proteomic technique. Therefore, human primary fibroblasts of the BJ strain, that were sequentially transduced with retroviral vectors encoding the genes for hTERT (BJ-T), SV40 ER (BJ-TE) and H-Ras V12 (BJ-TER), were used (Figure 1) [16]. Whereas the mortal BJ fibroblasts enter replicative senescence after prolonged culture, BJ-T cells prevent senescence due to expression of active telomerase. BJ-TE cells have disrupted RB- and p53-regulated checkpoints but remain anchorage-dependent and nontumorigenic. In contrast, BJ-TER cells represent a fully transformed phenotype including tumorigenicity in vivo, as previously shown [5]. For visualizing different proteomes, two-dimensional polyacrylamide gelelectrophorese (2D-PAGE) is the method of choice [17-19]. Therefore, this technique was used to get an overview of the proteome of the described cell lines that represent defined stages of the malignant transformation process. Our results give new insights in the proteome changes following the stepwise transformation of human cells. We present the characterization of 39 distinct differentially regulated protein spots which contain 67 proteins including PCNA, Peroxiredoxin-6 (PRDX6), Plasminogen activator inhibitor 2 (PAI-2), the cytoskeletal protein cytokeratin-7 (CK-7) and the cytoskeletal associated protein Annexin A2 (p36) as well as the heat shock proteins TRAP-1, HSP90-alpha and HSP90-beta.

\section{Materials and methods}

\section{Malignant Transformation - Generation of cell lines}

The cell lines BJ-T, BJ-TE and BJ-TER (Figure 1) were generated by sequential infection of the human diploid fibroblast strain BJ (ATCC CRL-2522) with retroviruses that were produced by transfection of the amphotropic packaging cell line PT67 (Becton Dickinson, Heidelberg, Germany) with the plasmids pWZL-blast3-hTERT, pZIP-SV776-1 or pLPC-HrasV12 [5,20,21]. Transduced cells were selected with $1 \mu \mathrm{g} / \mathrm{ml}$ blasticidin (Merck, Darmstadt, Germany), $400 \mu \mathrm{g} / \mathrm{ml} \mathrm{G418} \mathrm{(PAA,} \mathrm{Pasching,}$ Austria), or $0.75 \mu \mathrm{g} / \mathrm{ml}$ puromycin (Becton Dickinson), respectively. All cell lines were maintained in Dulbecco's Modified Eagle's Medium (Sigma, München, Germany) supplemented with $10 \%$ fetal bovine serum (Sigma), $1 \%$ penicillin G/streptomycin (Invitrogen, Karlsruhe, 


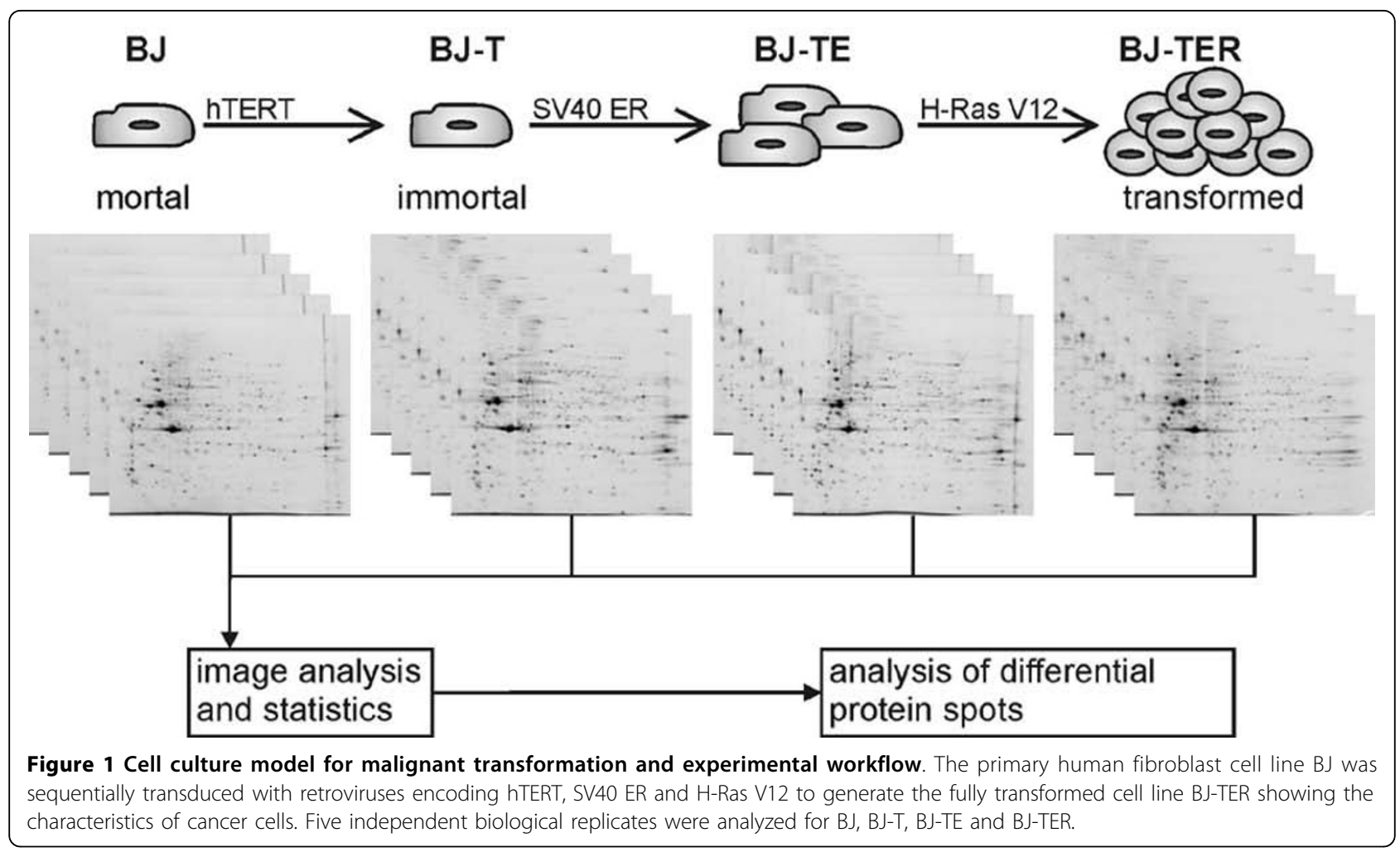

Germany) and 0.4\% Amphotericin (Sigma). Media were changed twice a week and cells were grown in a humidified atmosphere with $5 \% \mathrm{CO}_{2}$.

\section{Sample preparation}

Confluent cell plates with a diameter of $12 \mathrm{~cm}$ were washed twice with PBS (Sigma). Next, cells were scraped from the plate in $2 \mathrm{~mL}$ PBS and centrifuged for $10 \mathrm{~min}$ at $400 \times \mathrm{g}$ and $4^{\circ} \mathrm{C}$. The resulting pellet was lysed with 7 $M$ urea (AppliChem, Darmstadt), $2 \mathrm{M}$ thiourea (Merck), 2\% CHAPS (Merck) supplemented with 1 tablet protease inhibitor Complete Mini (Roche) per $10 \mathrm{~mL}$ buffer. Subsequently, samples were sonicated six times in an ultrasonic bath for 10 seconds with cooling intervals of one minute. Afterwards samples were centrifuged at $16000 \times \mathrm{g}$ for $10 \mathrm{~min}$. The supernatant was stored at $-80^{\circ} \mathrm{C}$. The protein amount was determined by Amido Black assay [22].

\section{D-PAGE}

Immediately before 2D-PAGE separation, $100 \mu \mathrm{g}$ of protein samples were diluted with IEF buffer, containing 7 $M$ urea, $2 \mathrm{M}$ thiourea, 2\% CHAPS, 5\% 2,2'-Dithiodiethanol (Sigma) and 2\% IPG buffer (GE Healthcare, Munich, Germany) to a final volume of $100 \mu \mathrm{L}$. That way prepared samples were used for 2D-PAGE as described elsewhere [17]. For the first dimension $24 \mathrm{~cm}$ IPG strips (3-10 NL) (GE Healthcare) and sample cups were used.
Isoelectric focusing was performed for a total of $50 \mathrm{kVh}$ (hold $150 \mathrm{~V}$ for $2 \mathrm{~h}$, hold $300 \mathrm{~V}$ for $2 \mathrm{~h}$, ramp to $500 \mathrm{~V}$ in $2 \mathrm{~h}$, ramp to $1000 \mathrm{~V}$ in $3 \mathrm{~h}$, ramp to $4000 \mathrm{~V}$ in $3 \mathrm{~h}$, hold at $6000 \mathrm{~V}$ for $7 \mathrm{~h}$ ) using an Ettan IPGphor (GE Healthcare). After IEF, IPG strips were equilibrated in two steps each $20 \mathrm{~min}$ in $6 \mathrm{M}$ urea, $30 \%$ glycine, $2 \%$ SDS, $50 \mathrm{mM}$ Tris $\mathrm{HCl}, \mathrm{pH} 8.8$ supplemented with 130 $\mathrm{mM}$ DTT and $280 \mathrm{mM}$ iodoacetamide respectively. Subsequently, IPG strips were placed on top of $10 \%$ polyacrylamide gels and Mark 12 (Invitrogen) was used as molecular weight marker for SDS-PAGE. The second dimension was carried out using the Ettan DALTSix (GE Healthcare). At the beginning $5 \mathrm{~W} /$ gel were applied for $30 \mathrm{~min}$ and afterwards $17 \mathrm{~W} /$ gel or max. $100 \mathrm{~W}$ until the running front reached the end of the glass plate. Gels were fluorescence stained with RuPBS as described elsewhere [23,24]. Scanned gels were compared and analyzed with the image analysis software PDQuest Advanced 8.0.1 (Bio-Rad, Munich, Germany) with $\mathrm{BJ}$ cells taken as control. The intensities of the gels were normalized and all protein spots exhibiting a minimum regulation by a factor of two were marked for further manual evaluation. Differential protein spots were excised, washed and digested [25].

\section{Mass spectrometry and data analysis}

Proteins were identified by nano-LC-MS/MS analysis. The analyses were conducted with either an LTQ XL 
using Xcalibur 2.0.5 and Bioworks 3.3.1 (Thermo-Scientific, Dreieich, Germany), a QStarElite in combination with AnalystQS 2.0 (Applied Biosystems, Darmstadt, Germany) or a Qtrap4000 in conjunction with Analyst 1.4.2 (Applied Biosystems). Samples were preconcentrated using a Synergi Hydro-RP C18 trapping column (100 $\mu \mathrm{m}$ ID, 2 cm length, $80 \AA$ A pore size, $4 \mu \mathrm{m}$ particle size; Phenomenex, Aschaffenburg, Germany) and afterwards separated on a Synergi Hydro-RP C18 main column $(75 \mu \mathrm{m}$ ID, $150 \mathrm{~mm}$ length, $80 \AA$ pore size, $2 \mu \mathrm{m}$ particle size; Phenomenex) using a linear binary gradient (solvent A: $0.1 \%$ formic acid in water; solvent B: $0.1 \%$ formic acid, $84 \%$ acetonitril) at a flow rate of $270 \mathrm{~nL} /$ min. Full MS scans from 300 to 1500 or $2000 \mathrm{~m} / \mathrm{z}$ respectively were acquired, and the three to five most intensive peptide ions were subjected to further fragmentation, depending on the mass spectrometer. Duplicate detection of a single $\mathrm{m} / \mathrm{z}$ within $30 \mathrm{~s}$ led to dynamic exclusion.

LTQ raw data-files were converted into mgf-files using the supplied version of LCQ-DTA.EXE as plug-in to Mascot Daemon with the following parameters: (a) minimum mass: 400, (b) maximum mass 3000, (c) grouping tolerance 1.4, (d) min. scans/group: 1, (e) intermediate scans: 1, (f) precursor charge: auto. QStarElite and Qtrap4000 wiff-files were converted into mgffiles using the respective mascot.dll with the parameters: (a) precursor mass tolerance for grouping 0.05 (QStarElite) 0.2 (Qtrap), (b) max. number cycles between groups 4 (QStarElite) 1 (Qtrap), (c) min. number cycles per group 1, (d) Remove peaks if intensity $<0.05$ (QStarElite) $<0.1$ (Qtrap) \% of maximum, (e) centroid all MS/ MS data, (f) reject spectra if less than 10 peaks. Protein identification was performed using Mascot ${ }^{\mathrm{Tw}}$, Version 2.2.0 (Matrix Science, London, UK) and the SwissProt database (02-03-2006) with 208005 entries. Mascot parameters were choosen as follows: protease: trypsin, fixed modifications: carbamidomethyl (C), variable modifications: oxidation (M), taxonomy: Homo sapiens (13538 entries), missed cleavages: 2, peptide and MS/MS tolerance: \pm 0.2 (QStarElite) \pm 0.4 (Qtrap) \pm 1.5 (LTQ), significance threshold: $\mathrm{p}<0.05$. For spots not satisfactorily identified with the SwissProt database an additional search was conducted against human IPI (version v3.26, 67665 entries) using Mascot ${ }^{\mathrm{m}}$, Version 2.1 (Matrix Science) with the same parameters used for SwissProt. Significant MS/MS peptide identifications were verified manually.

\section{Data interpretation}

Hierarchical clustering and visualization of the intensities of regulated protein spots according to cell line and regulation pattern was accomplished as described elsewhere [26]. Subcellular localization of identified proteins was extracted from the UniProt database http://www. uniprot.org/ in December 2009. At the same time functional annotation of the identified proteins was allocated using the Go Term Mapper website http://go.princeton. edu/cgi-bin/GOTermMapper and the human GO Slim categories. Identified proteins were grouped into the categories for biological process.

\section{Western Blot}

Cells pellets, previously flash frozen in liquid nitrogen and stored at $-80^{\circ} \mathrm{C}$, were lysed in NP40 buffer $(50 \mathrm{mM}$ Tris- $\mathrm{HCl}$ ph 8.0, $150 \mathrm{mM} \mathrm{NaCl}, 5 \mathrm{mM}$ EDTA ph 8.0, $2 \%$ NP40) supplemented with protease inhibitor cocktail (Roche). $30 \mu \mathrm{g}$ of soluble protein was separated on 4$12 \%$ NuPAGE Bis-Tris gels (Invitrogen) and transferred to ECL nitrocellulose membranes by wet blotting. Membranes were blocked with $10 \%$ non fat dry milk in TBST (5 mM Tris, $15 \mathrm{mM} \mathrm{NaCl}, \mathrm{pH}$ 7.6, 0.1\% Tween20). Primary antibodies were diluted in TBST with $5 \%$ non fat dry milk at the following concentrations: PCNA (sc-56, Santa Cruz, $1 \mu \mathrm{g} / \mathrm{ml}$ ), PRDX6 (ab92322, Abcam), HSP90-alpha (AB3466, Millipore, $2 \mu \mathrm{g} / \mathrm{ml}$ ), HSP90-beta (AB3468, Millipore, $2 \mu \mathrm{g} / \mathrm{ml}$ ), PAI2 (sc-25745, Santa Cruz, $1 \mu \mathrm{g} / \mathrm{ml}$ ), and $\beta$-Actin (ab6276, Abcam, $1 \mu \mathrm{g} / \mathrm{ml}$ ). Detection was performed with horseradish peroxidase or Alexa Fluor 680 linked secondary antibodies using enhanced chemiluminescence (Thermo Fisher) or infrared imaging (Odyssey, LI-COR).

\section{Results}

The cell culture model for malignant transformation consisting of the four cell lines BJ, BJ-T, BJ-TE and BJTER was analyzed by a differential 2D-PAGE approach. To compare the protein spot patterns of the different cell lines, a minimum of five cell plates was processed to obtain five independent biological replicates for each cell line (gels shown in Additional file 1). Analysis and subsequent manual validation of the PDQuest output resulted in 39 differentially regulated protein spots among the four cell lines. Figure 2 shows a representative 2D-PAGE gel from cell line BJ and the protein spots which are regulated among the four cell lines.

To determine which protein spots were regulated by which genetic alteration, the normalized intensities of each regulated protein spot were used for hierarchical clustering. Protein spots were sorted according to their regulation pattern using the software Cluster [26] and results are shown in Figure 3. It is evident that many protein spots show their strongest regulation between the cell lines BJ-T and BJ-TE caused by the insertion of SV40 ER. During the malignant transformation from BJ (via $\mathrm{BJ}-\mathrm{T}$ and $\mathrm{BJ}-\mathrm{TE}$ ) to BJ-TER the protein spots become continuously up- or down-regulated except a few spots. As an example spot 22 shows increased peak 


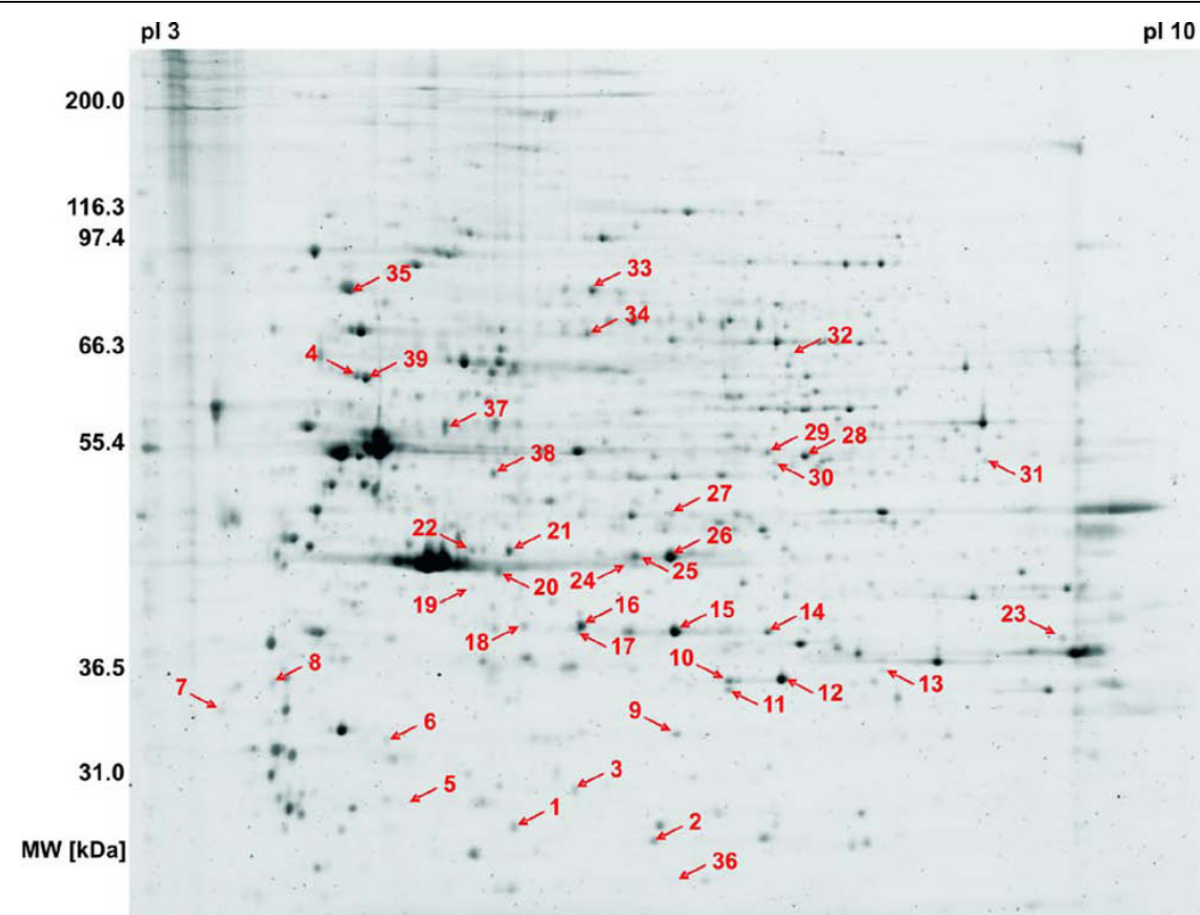

Figure 2 Proteome visualization of the malignant transformation model cell lines by 2D-PAGE. A representative 2D-gel from the cell line BJ stained with RuBPS is shown. Regulated protein spots are indicated with arrows and numbers. The degree of regulation for these protein spots is given in Figure 3, while identified proteins are listed in Table 2.

intensity in stage BJ-T compared to BJ and is absent in BJ-TE, but up-regulated again due to the $\mathrm{H}$-Ras transition. Therefore, it may be concluded that the majority of the regulated proteins during malignant transformation is either continuously up- or down-regulated. Moreover, for most protein spots the in-group variability is low, indicating good reproducibility. Beside the visualization of the hierarchical clustering, the number of spots up-or down-regulated within the transitions is summarized in Table 1 . In addition, spots that were not detectable before or after a transition are indicated.

Identification of the proteins in differentially regulated 2D-PAGE spots was accomplished by nano-LCMS/MS. While 39 protein spots showing significant changes in intensity, 32 could be readily identified, corresponding to an identification rate of $82 \%$. Moreover, for 25 protein spots more than a single protein was identified. Table 2 lists the identified proteins according to the spot number. Regulation of spot 24 could not be determined, because this protein spot is absent in the gels of the cell lines BJ and BJ-T. Therefore the normalized intensities and the error estimated by PDQuest were included in Table 2 instead. For more detailed protein information (e.g. MW, pI) also see the Additional file 1. In total, the analysis of the 39 differential protein spots resulted in the identification of 67 proteins.
To investigate a relation between the introduction of a specific genetic alteration and the proteins identified in the thereby regulated spots in terms of function and localization, the protein spots were grouped according to their regulation (as listed in Table 1) and the respective proteins were further analyzed using UniProt database entries for subcellular localization and the Go Term Mapper website and human GO Slim categories for functional annotation. Results are depicted in Figure 4 and Figure 5. Altogether seven proteins were identified within the six differential protein spots between BJ and $\mathrm{BJ}-\mathrm{T}$ cell line, 39 proteins within the 27 spots between $\mathrm{BJ}-\mathrm{T}$ and $\mathrm{BJ}-\mathrm{TE}$ and eight proteins within the four spots that were differentially expressed between BJ-TE and BJTER. For the multi-step transitions see Table 1. Regarding the subcellular localization (Figure 4), at least a quarter of the proteins were derived from cytoplasm during all transitions. In contrast, mitochondrial and nuclear proteins were mainly involved in the transition from $\mathrm{BJ}-\mathrm{T}$ to $\mathrm{BJ}-\mathrm{TE}$, whereas proteins localized in the endoplasmic reticulum were found exclusively in the multi-step transitions. Moreover, lysosomal and secreted proteins were not found in the Ras transition. Here it needs to be mentioned that secreted proteins might have been lost during cell culture. Moreover, the separation of membrane proteins by conventional 2D-PAGE is not sufficient and has to be met by alternative 


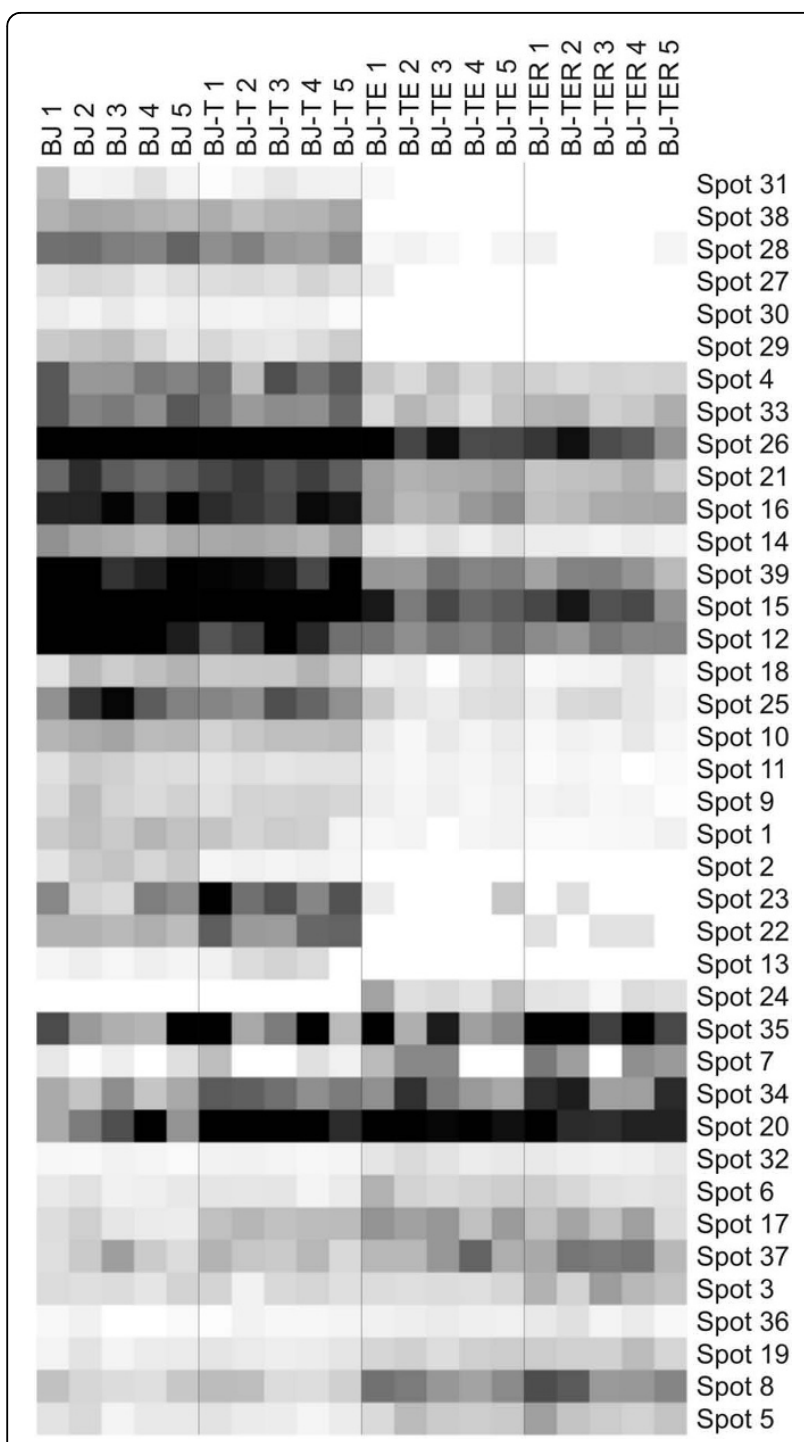

Figure 3 Hierarchical clustering of intensities of regulated protein spots according to cell line and regulation pattern. The five 2D-gel replicates from each cell line are numbered; each column represents one gel; each row represents a protein spot. The spot intensities are indicated in grayscale (white $=$ no intensity; black $=$ highest intensity).

separation strategies [27]. Nevertheless, we found some membrane proteins particularly in the multi-step transitions. Analogous to the subcellular localization, functional classification of the identified proteins was carried out and the single-step transitions were shown in Figure 5. Compared to the others, in the hTERT transition fewer amounts of proteins are identified belonging to the GO slim categories metabolism and biosynthetic process. In these categories and cell communication the percentile amount of proteins identified in the H-Ras transition are increased. Proteins involved in cell death, multicellular organismal processes and extracellular structure organization are identified only in the hTERT and SV40 ER transition. Moreover, introduction of SV40 ER also affects proteins involved in secretion, amino acid metabolism, cell differentiation and behavior.

To condense the results found so far, proteins identified within the regulated spots are displayed in Table 3 according to the transitions and the respective features. Interestingly, two proteins, Protein phosphatase methylesterase 1 (PPME1) and Solute carrier family 25 member 24 (SLC25A24), were identified together in the up-regulated spot 24. Within the same transition (SV40 ER) these proteins were also identified in two different down-regulated spots.

Summarizing the results, we detected 39 differential protein spots within the cell culture model for malignant transformation, identified 67 proteins, and grouped them according to their stage of regulation, localization and function. One major problem of 2D-PAGE is the detection of multiple proteins per spot [17], thus a precise quantification can only be conducted for single-protein spots. Therefore, in a separate table (Table 4), we listed the seven spots containing only a single protein, which was severalfold identified in the replicate gels of the cell line thereby proving the regulation directly. In addition, at least three spectra of different peptides were required for identification to be included into Table 4 . The unambiguously regulated proteins are PRDX6, PCNA, p36, PAI-2, TRAP-1 and CK-7. In spot 35 two homologous proteins (HSP90-alpha and HSP90-beta) were identified. The proteins identified in the other 32 protein spots need to be further validated by other methods.

Widely known issues of 2D-PAGE are multiple protein identifications per spot and shifting of proteins in the 2D-Gel pattern due to modifications. To verify the expression level for some candidate proteins, Western Blot analyses were conducted (Figure 6). The Western Blots of selected proteins confirm that PCNA is upregulated due to SV40 ER and PAI2 is most abundant in cell line BJ-T. The homologous proteins HSP90-alpha and HSP90-beta detected by 2D-PAGE within spot 35 can be detected separately with Western Blots. Both HSP90-alpha and HSP90-beta show regulation. Complete HSP90-alpha, HSP90-beta and PRDX6 levels differ from the regulation pattern of the respective 2D-PAGE spots, but show the same direction of regulation considering the full transformation process.

\section{Discussion}

A cell culture model for malignant transformation offers the possibility to study cancer development following specified genetic alterations in front of a defined genetic background. During the last decade, 2D-PAGE has been the standard for separation, visualization and 
Table 1 Spots regulated within the transitions and the number of identified proteins

\begin{tabular}{|c|c|c|c|c|c|}
\hline transition & up-regulated spots & $\begin{array}{l}\text { sum of up- } \\
\text { regulated } \\
\text { spots }\end{array}$ & down-regulated spots & $\begin{array}{l}\text { sum of down- } \\
\text { regulated spots }\end{array}$ & $\begin{array}{r}\text { sum of } \\
\text { identified } \\
\text { proteins }\end{array}$ \\
\hline $\begin{array}{l}\text { BJ } \rightarrow \text { BJ-T } \\
\text { (hTERT) }\end{array}$ & $13,17,20,23$ & 4 & 2,31 & 2 & 7 \\
\hline $\begin{array}{l}\text { BJ-T } \rightarrow \text { BJ-TE } \\
(\text { SV40) }\end{array}$ & $5,6,7,8,24^{*}, 32$ & 6 & $\begin{array}{c}1,2^{*}, 4,9,10,11,13^{*}, 14,16,18,21,22^{*}, 23,25, \\
26,28,29^{*}, 30^{*}, 31,33,38^{*}\end{array}$ & 21 & 39 \\
\hline $\begin{array}{l}\text { BJ-TE } \rightarrow \text { BJ-TER } \\
\text { (RAS) }\end{array}$ & $22^{*}, 35$ & 2 & $27^{*}, 31^{*}$ & 2 & 8 \\
\hline $\begin{array}{l}\text { BJ } \rightarrow \text { BJ-TE } \\
(\text { hTERT + SV40) }\end{array}$ & $\begin{array}{c}5,6,7,8,17,19,24^{*} \\
32\end{array}$ & 8 & $\begin{array}{c}1,2^{*}, 4,9,10,11,12,13^{*}, 14,15,16,18,22^{*}, 23, \\
25,26,28,29^{*}, 30^{*}, 31,33,38^{*}, 39 \\
\end{array}$ & 23 & 48 \\
\hline $\begin{array}{l}\text { BJ-T } \rightarrow \text { BJ-TER } \\
(\text { SV40 + RAS) }\end{array}$ & $\begin{array}{c}3,5,7,8,19,24^{*}, 35 \\
36\end{array}$ & 8 & $\begin{array}{c}1,2^{*}, 4,9,10,11,13^{*}, 14,16,18,21,22,23,25,26, \\
27^{*}, 28,29^{*}, 30^{*}, 31^{*}, 38^{*}, 39\end{array}$ & 22 & 47 \\
\hline $\begin{array}{l}\text { BJ } \rightarrow \text { BJ-TER } \\
\text { (all) }\end{array}$ & $\begin{array}{c}3,5,7,8,17,19,24^{*} \\
32,34,35,36,37\end{array}$ & 12 & $\begin{array}{c}1,2^{*}, 4,9,10,11,12,13^{*}, 14,15,16,18,21,22,23, \\
25,26,27^{*}, 28,29^{*}, 30^{*}, 31^{*}, 33,38^{*}, 39\end{array}$ & 25 & 63 \\
\hline
\end{tabular}

The numbers of spots up- or down-regulated within the transitions are listed and summed up. The number of identified proteins within regulated spots of a particular transition is presented in the right column. Spots marked with an asterisk are not detectable before or after a transition.

comparison of closely related proteomes. We decided to improve the reliability of results by using a minimum of five cell culture plates from each cell line (Figure 1). Each plate was processed independently giving at least five biologically independent recurrences for each cell line. Only protein spots showing regulation changes independent of the biological variance are relevant changes originating from genetic alterations.

Besides gel to gel variation, the choice of the appropriate protein staining method has major influences on the image analysis with existing software. Commonly, silver or Coomassie staining is used for the detection of proteins in 2D-gels. Silver staining is a very sensitive protein visualization method, but suffers from low reproducibility, because over-staining effects (donut- or crater spots) and potential interference with subsequent MS occurs $[28,29]$. Although colloidal Coomassie staining offers better compatibility with MS compared to many silver-staining protocols, it is less sensitive [30]. To overcome these limitations we used Ruthenium(II)tris-bathophenanthroline disulfonate (RuBPS) [31]. In comparison to silver staining RuBPS fluorescent staining shows a higher linearity in signal intensity and is more reproducible. Furthermore, RuPBS is more sensitive than Coomassie and offers compatibility with MS [23,24].

In addition to the use of a MS compatible staining method the MS method itself has a major effect on the success of identification. Using nano-LC-MS/MS, we had an identification rate of $82 \%$ in this study. A related proteomic approach, however, had a rate of roughly $50 \%$ [32], which is most probably due to the use of MALDIMS. Moreover, it was previously shown that the use of MALDI-MS and LC-ESI-MS/MS in combination achieves the best results [33]. However, superior separation and sensitivity by nano-LC-MS/MS also led to the identification of more than a single protein in several spots - a situation often encountered in 2D-PAGE studies [17]. The utilized mass analyzers are getting more sensitive; thus it is possible to identify also very low abundant proteins in the spots co-migrating in the presence of high abundant proteins. Although, more than 5000 proteins can be resolved by 2D-PAGE approaches simultaneously and $\sim 2000$ proteins routinely [17], depending on used gel size and $\mathrm{pH}$ gradient. The complexity of complete cell lysates with presumably several hundred thousand protein features [34] can easily surpass the available resolution. Therefore, the detection of more than one protein per spot needs to be expected. In these cases it remains unclear which of the detected proteins is regulated and other methods need to be employed for further validation.

Western Blot analysis is a common method to verify 2D-PAGE results regarding the known restrictions: multiple protein identifications per spot and shifting of proteins in the 2D-gel pattern due to modifications. Our Western Blots support the findings of 2D-PAGE with respect to the full transformation process. However, the 2D-PAGE regulation pattern in some cases differs from the Western Blot results. A possible explanation could be that in 2D-PAGE single protein species are detected whereas in Western Blots the total expression level of a protein including all of its isoforms and modifications is analyzed.

Besides these technical considerations, many changes on the proteome level were detected in the malignant transformation model that are worth to be discussed. BJ-TE cells have disrupted RB- and p53-regulated checkpoints but remain anchorage-dependent and nontumorigenic. In this step more pathways are altered in a detectable manner than in the other two steps. SV40 LT inactivates $R B$ and $p 53$ due to binding of $R B$ via its $\mathrm{N}$ terminal LXCXE motif and p53 via its bipartite C- 
Table 2 Identified proteins within the protein spots showing at least two-fold up- or down-regulation between the cell lines of the malignant transformation model

\begin{tabular}{|c|c|c|c|c|c|c|c|}
\hline Spot No & SwissProt ID & gene & BJ & $T$ & $\mathrm{TE}$ & TER & IPI ID \\
\hline \multirow[t]{2}{*}{1} & P04792 & HSPB1 & 1,00 & 0,69 & 0,17 & 0,13 & \\
\hline & Q13242 & SFRS9 & & & & & \\
\hline 2 & P30041 & PRDX6 & 1,00 & 0,25 & 0,00 & 0,00 & \\
\hline \multirow[t]{2}{*}{3} & Q06323 & PSME1 & 1,00 & 0,98 & 1,03 & 2,05 & \\
\hline & P35232 & $\mathrm{PHB}$ & & & & & \\
\hline 4 & Q9UNF0 & PACSIN2 & 1,00 & 1,10 & 0,40 & 0,34 & \\
\hline \multirow[t]{3}{*}{5} & P43487 & RANBP1 & 1,00 & 0,79 & 2,18 & 2,61 & \\
\hline & P25788 & PSMA3 & & & & & \\
\hline & P07686 & HEXB & & & & & \\
\hline \multirow[t]{3}{*}{6} & Q15691 & MAPRE1 & 1,00 & 1,03 & 2,46 & 1,69 & \\
\hline & Q99426 & $\mathrm{TBCB}$ & & & & & \\
\hline & P61247 & RPS3A & & & & & \\
\hline 7 & N.D. & & 1,00 & 1,99 & 5,53 & 5,98 & \\
\hline \multirow[t]{2}{*}{8} & P12004 & PCNA & 1,00 & 1,10 & 2,59 & 2,97 & \\
\hline & P01584 & IL1B & & & & & \\
\hline 9 & N.D. & & 1,00 & 0,88 & 0,27 & 0,20 & \\
\hline 10 & N.D. & & 1,00 & 0,76 & 0,21 & 0,16 & \\
\hline 11 & 000463 & TRAF5 & 1,00 & 0,71 & 0,30 & 0,16 & \\
\hline \multirow[t]{2}{*}{$\overline{12}$} & P13716 & ALAD & 1,00 & 0,72 & 0,48 & 0,44 & \\
\hline & 014656 & TOR1A & & & & & \\
\hline 13 & P07355 & ANXA2 & 1,00 & 2,58 & 0,00 & 0,00 & \\
\hline \multirow[t]{2}{*}{$\overline{14}$} & P31942 & HNRPH3 & 1,00 & 0,99 & 0,29 & 0,18 & \\
\hline & P02545 & LMNA & & & & & \\
\hline 15 & N.D. & & 1,00 & 0,62 & 0,39 & 0,40 & \\
\hline 16 & N.D. & & 1,00 & 0,95 & 0,41 & 0,34 & \\
\hline \multirow[t]{3}{*}{$\overline{17}$} & O60664 & M6PRBP1 & 1,00 & 2,30 & 3,26 & 2,40 & \\
\hline & P06748 & NPM1 & & & & & \\
\hline & P07195 & LDHB & & & & & \\
\hline 18 & P08670 & VIM & 1,00 & 1,03 & 0,33 & 0,23 & \\
\hline \multirow[t]{3}{*}{19} & Q9UJZ1 & STOML2 & 1,00 & 1,24 & 2,46 & 2,81 & \\
\hline & Q9NWT6 & HIF1AN & & & & & \\
\hline & 094905 & ERLIN2 & & & & & \\
\hline \multirow[t]{2}{*}{20} & P05120 & SERPINB2 & 1,00 & 2,18 & 1,84 & 1,50 & \\
\hline & P60709 & ACTB & & & & & \\
\hline 21 & P60709 & ACTB & 1,00 & 1,09 & 0,53 & 0,38 & \\
\hline \multirow[t]{4}{*}{22} & P60709 & ACTB & 1,00 & 1,80 & 0,00 & 0,39 & \\
\hline & Q12905 & ILF2 & & & & & \\
\hline & P60842 & EIF4A1 & & & & & \\
\hline & O60664 & M6PRBP1 & & & & & \\
\hline 23 & N.D. & & 1,00 & 2,14 & 0,42 & 0,36 & \\
\hline \multirow[t]{2}{*}{24} & Q9Y570 & PPME1 & 0 & 0 & 235347 & 119221 & \\
\hline & Q6NUK1 & SLC25A24 & & & & & IPI00337494 \\
\hline \multirow[t]{3}{*}{25} & Q9Y570 & PPME1 & 1,00 & 0,79 & 0,20 & 0,16 & \\
\hline & Q13148 & TARDBP & & & & & \\
\hline & P60709 & ACTB & & & & & \\
\hline \multirow[t]{4}{*}{26} & P23526 & AHCY & 1,00 & 0,85 & 0,40 & 0,33 & \\
\hline & P36507 & MAP2K2 & & & & & \\
\hline & none & none & & & & & IPI00410404 \\
\hline & Q6NUK1 & SLC25A24 & & & & & IPI00337494 \\
\hline
\end{tabular}


Table 2 Identified proteins within the protein spots showing at least two-fold up- or down-regulation between the cell lines of the malignant transformation model (Continued)

\begin{tabular}{|c|c|c|c|c|c|c|}
\hline \multirow[t]{2}{*}{27} & \multirow{2}{*}{$\begin{array}{l}\text { P06733 } \\
\text { P68104 }\end{array}$} & \multirow{2}{*}{$\begin{array}{l}\text { ENO1 } \\
\text { EEF1A1 }\end{array}$} & \multirow[t]{2}{*}{1,00} & \multirow[t]{2}{*}{1,07} & \multirow[t]{2}{*}{0,57} & \multirow[t]{2}{*}{0,00} \\
\hline & & & & & & \\
\hline \multirow[t]{6}{*}{28} & P09913 & IFIT2 & 1,00 & 0,79 & 0,06 & 0,08 \\
\hline & P00352 & $\mathrm{ALDH} 1 \mathrm{~A} 1$ & & & & \\
\hline & Q15813 & TBCE & & & & \\
\hline & P12268 & IMPDH2 & & & & \\
\hline & 043175 & PHGDH & & & & \\
\hline & P11413 & G6PD & & & & \\
\hline \multirow[t]{3}{*}{29} & P00352 & ALDH1A1 & 1,00 & 0,71 & 0,00 & 0,00 \\
\hline & 043175 & PHGDH & & & & \\
\hline & Q9UMS4 & PRPF19 & & & & \\
\hline \multirow[t]{2}{*}{30} & P11413 & G6PD & 1,00 & 0,74 & 0,00 & 0,00 \\
\hline & P28838 & LAP3 & & & & \\
\hline 31 & N.D. & & 1,00 & 0,49 & 0,23 & 0,00 \\
\hline 32 & Q12931 & TRAP1 & 1,00 & 1,36 & 3,16 & 2,15 \\
\hline \multirow[t]{2}{*}{33} & P06396 & GSN & 1,00 & 0,88 & 0,36 & 0,48 \\
\hline & Q96TA1 & FAM129B & & & & \\
\hline \multirow[t]{4}{*}{34} & P20591 & $M \times 1$ & 1,00 & 1,78 & 1,59 & 2,10 \\
\hline & P13667 & PDIA4 & & & & \\
\hline & P11021 & HSPA5 & & & & \\
\hline & P17812 & CTPS & & & & \\
\hline \multirow[t]{2}{*}{35} & P08238 & HSP90AB1 & 1,00 & 0,99 & 0,97 & 2,07 \\
\hline & P07900 & HSP90AA1 & & & & \\
\hline \multirow[t]{3}{*}{36} & P30048 & PRDX3 & 1,00 & 0,94 & 1,86 & 2,07 \\
\hline & P62491 & RAB11A & & & & \\
\hline & P27635 & RPL10 & & & & \\
\hline \multirow[t]{6}{*}{37} & P10809 & HSPD1 & 1,00 & 1,10 & 1,79 & 2,09 \\
\hline & P68363 & K-ALPHA-1 & & & & \\
\hline & P07237 & P4HB & & & & \\
\hline & P60709 & ACTB & & & & \\
\hline & P54578 & USP14 & & & & \\
\hline & P48643 & CCT5 & & & & \\
\hline 38 & P08729 & KRT7 & 1,00 & 0,96 & 0,00 & 0,00 \\
\hline \multirow[t]{3}{*}{39} & Q969P6 & TOP1MT & 1,00 & 0,85 & 0,43 & 0,38 \\
\hline & P08670 & VIM & & & & \\
\hline & P14625 & HSP90B1 & & & & \\
\hline
\end{tabular}

Shown are the corresponding SwissProt ID, gene name and the average regulation of the protein spot normalized to the spot intensity in the BJ cells (bold = upregulation, bold italic $=$ down-regulation). For detailed information see Additional file 1.

terminal binding domain [35]. Unlike SV40 LT the exact contribution of SV40 ST to cellular transformation remains elusive. It is known that SV40 ST binds PP2A, stimulates the phosphorylation of Protein Kinase $B$ (Akt) and affects the c-Myc pathway [13,14].

Besides the transition $\mathrm{BJ}-\mathrm{T}$ to $\mathrm{BJ}-\mathrm{TE}$, the other transitions also significantly affect the proteome as detectable by 2D-PAGE. A thorough study on the H-Ras transformation step was done by Young and coworkers who investigated the proteomic changes associated with expression of $\mathrm{H}$-Ras in a human ovarian epithelial cell line that was immortalized with SV40 LT, ST and the human catalytic subunit of telomerase [32]. They identified 32 proteins that were up- or down-regulated more than 1.5 fold. Moreover, they used a narrower $\mathrm{pH}$ range from 4 to 7 resulting in a higher resolution of this part of the proteome. Proteins detected are involved in cellular processes like metabolism, redox balance, calcium signaling, apoptosis and cellular methylation. The unambiguously regulated proteins identified in our current analysis were not detected by their approach. Thus the cell line reflecting the tissue origin possibly has a major 


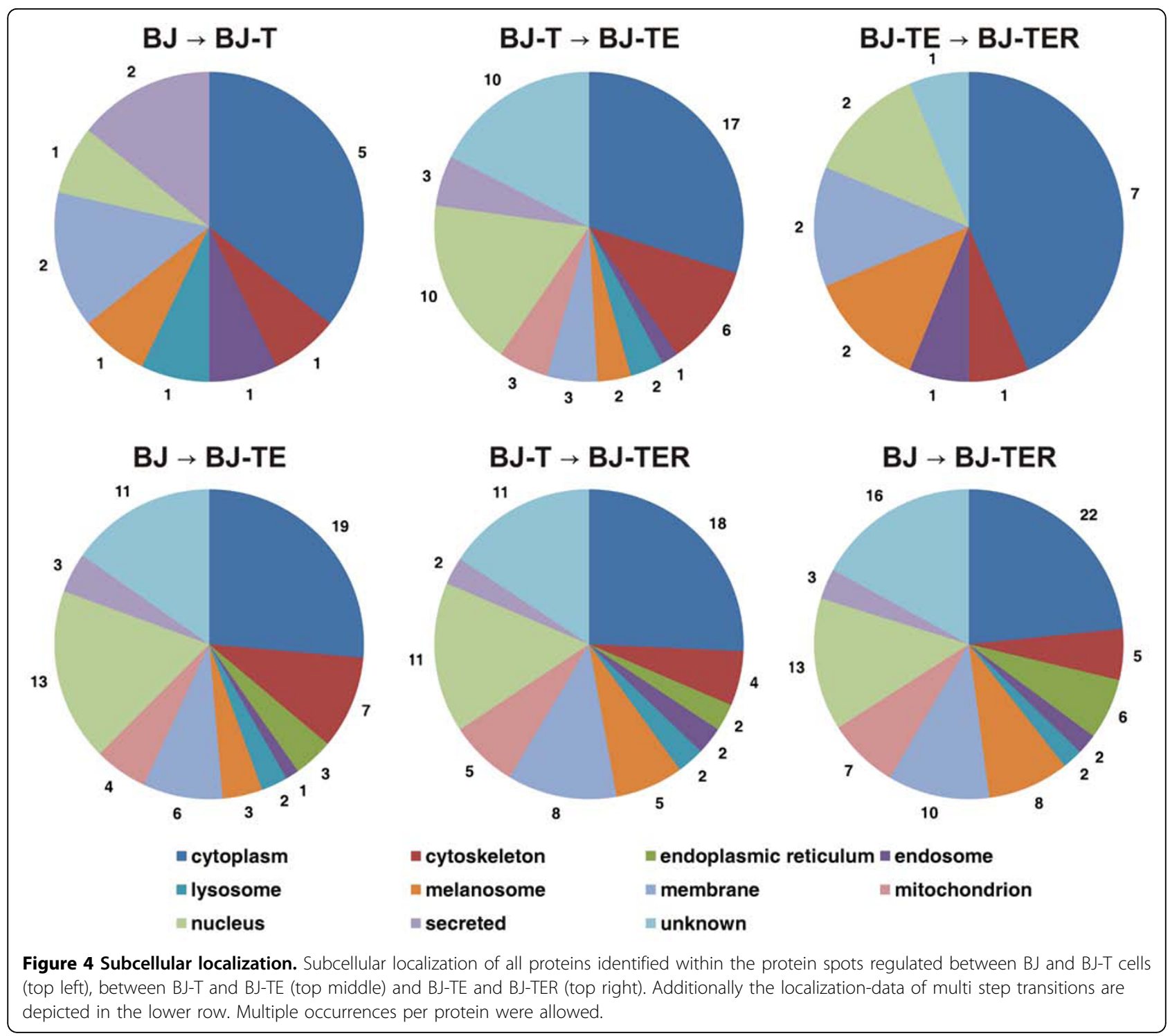

not yet understood impact on the proteins regulated by H-Ras.

Cellular localization and function of a list of proteins point to the ongoing molecular changes (Figure 4 and 5). Avoiding cell death and apoptosis is an essential step during malignant transformation. SV40 LT alone bypasses senescence [36,37], but does not fully immortalize human cells, as such modified cells eventually undergo crisis. However, in combination with hTERT immortalization is achieved $[11,38]$. Thus, finding proteins involved in cell death in the hTERT and SV40 transition but not in H-Ras transition is not astonishing. Moreover, our results reflect the finding that human cells are immortalized by hTERT in combination with SV40 LT. Furthermore, such data-depiction and interpretation can give a first hint at ongoing molecular changes in an unknown dataset and enables fast data-access.

Similarly, Table 3 depicts the direct link between potentially regulated proteins and the respective transition features. Interestingly, the proteins PPME1 and SLC25A24 were identified both in the up-regulated spot 24 and within the same transition these proteins were also identified in two different down-regulated spots (spot 25 and 26). Thus, they are potentially modified due to SV40 ER expression and therefore moving in the 2D-gel spot pattern.

Focusing on the seven proteins listed in Table 4, PCNA is a commonly used proliferation marker. Within the cell culture model for malignant transformation higher proliferation is observed due to SV40 ER integration and consequently an up-regulation of 


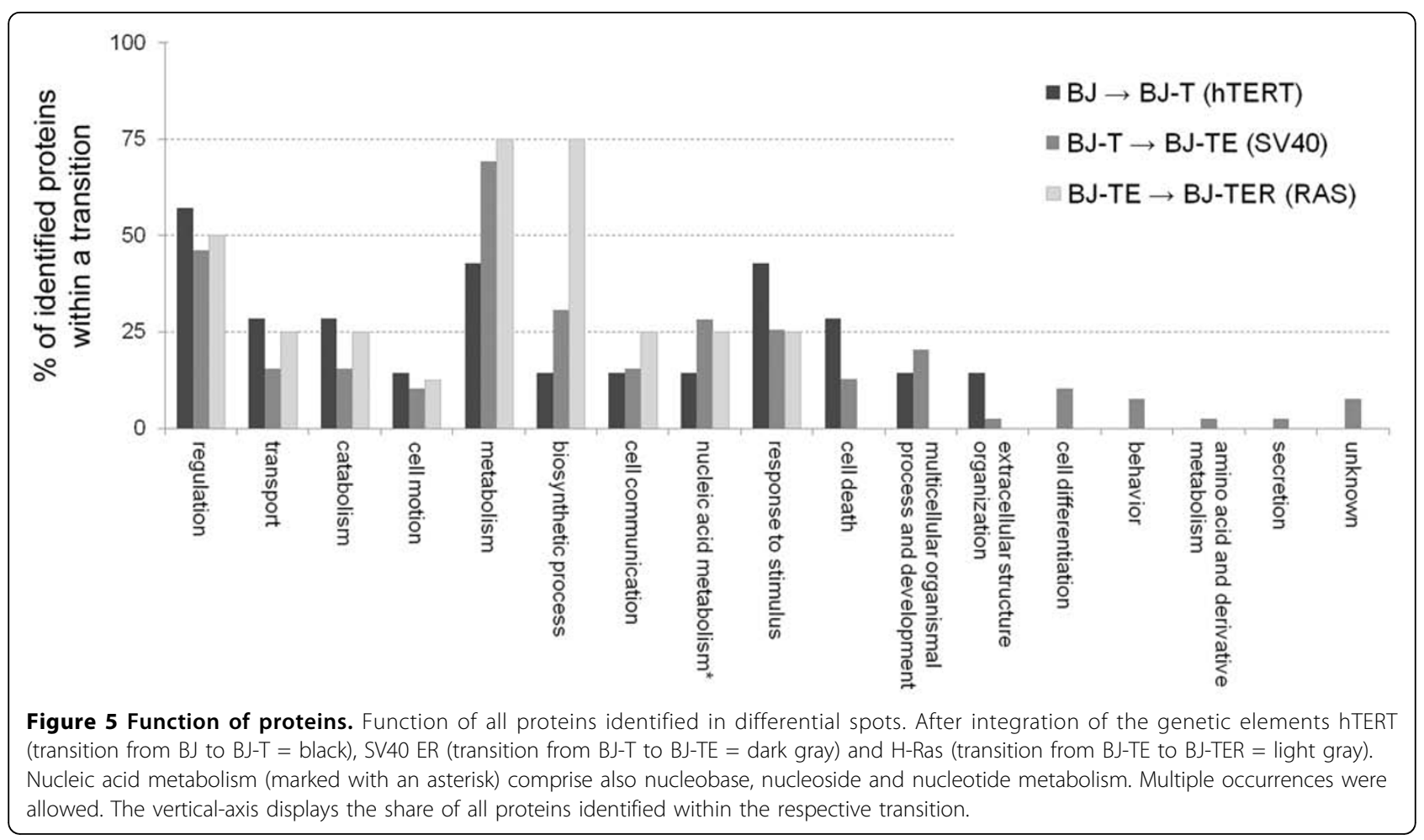

PCNA after this transition was detectable with 2DPAGE and reinforced by Western Blot. So the upregulation of PCNA confirms the observations on cell culture growth.

PRDX6 has not been described previously to be regulated due to hTERT and SV40 ER integration. Here, we show that the integration of hTERT results in a downregulation of the PRDX6 spot and the subsequent introduction of SV40 ER results in the complete absence of this spot. In contrast, Western Blot analysis of PRDX6 shows no difference in abundance between $\mathrm{BJ}$ and $\mathrm{BJ}-\mathrm{T}$, but indeed PRDX6 is clearly down-regulated due to SV40 ER and nearly absent in BJ-TER. However, another study showed the up-regulation of PRDX6 in metastatic cells [39] and, moreover, PRDX6 was found to be up-regulated in sera of many patients with esophageal squamous cell carcinoma [40]. Again, we can only speculate that the direction of regulation is influenced

Table 3 Transition features and the presumably regulated proteins

\begin{tabular}{|c|c|c|c|}
\hline transition & transition feature & genes presumably up-regulated proteins & $\begin{array}{l}\text { genes presumably down- } \\
\text { regulated proteins }\end{array}$ \\
\hline $\begin{array}{l}\text { BJ } \rightarrow \text { BJ-T } \\
(\text { hTERT) }\end{array}$ & prevention of senescence & ACTB, ANXA2, LDHB, M6PRBP1, NPM1, SERPINB2 & PRDX6 \\
\hline $\begin{array}{l}\text { BJ-T } \rightarrow \text { BJ-TE } \\
(\text { SV40) }\end{array}$ & $\begin{array}{l}\text { proliferation and prevention of } \\
\text { apoptosis }\end{array}$ & $\begin{array}{l}\text { HEXB, IL1B, MAPRE1, PCNA, PPME1, PSMA3, RANBP1, } \\
\text { RPS3A, SLC25A24, TBCB, TRAP1 }\end{array}$ & $\begin{array}{l}\text { ACTB, AHCY, ALDH1A1, ANXA2, } \\
\text { EIF4A1, } \\
\text { FAM129B, G6PD, GSN, HNRPH3, } \\
\text { HSPB1, } \\
\text { IFIT2, ILF2, IMPDH2, } \\
\text { IPI00410404, } \\
\text { KRT7, LAP3, LMNA, M6PRBP1, } \\
\text { SFRS9, } \\
\text { MAP2K2, PACSIN2, PHGDH, } \\
\text { PPME1, PRDX6, } \\
\text { PRPF19, SLC25A24, TARDBP, } \\
\text { TBCE, TRAF5, VIM }\end{array}$ \\
\hline $\begin{array}{l}\text { BJ-TE } \rightarrow \text { BJ-TER } \\
\text { (RAS) }\end{array}$ & $\begin{array}{l}\text { prevention of anoikis and growth- } \\
\text { factor indepandancy }\end{array}$ & ACTB, EIF4A1, HSP90AA1, HSP90AB1, ILF2, M6PRBP1 & EEF1A1, ENO1 \\
\hline
\end{tabular}

The respective transition features and the genes of proteins identified in the spots up- or down-regulated within the transitions are listed. In one case the protein ID is listed. PPME1 and SLC25A24 were identified both in the up-regulated spot 24 and within the same transition these proteins were also identified in two different down-regulated spots. Hence, they are mentioned within the presumably up- and down-regulated proteins of the SV40 ER transition. 
Table 4 List of all unequivocally identified proteins

\begin{tabular}{|c|c|c|c|c|c|c|c|c|c|c|c|c|}
\hline $\begin{array}{l}\text { spot } \\
\text { no }\end{array}$ & $\begin{array}{l}\text { SwissProt } \\
\text { ID }\end{array}$ & protein & $\begin{array}{l}\text { protein } \\
\text { name } \\
\text { abbreviation }\end{array}$ & gene & $\mathrm{pl}$ & MW & BJ & $T$ & $\mathrm{TE}$ & TER & $\begin{array}{l}\text { Subcellular } \\
\text { localization }\end{array}$ & $\begin{array}{l}\text { selection of biological } \\
\text { processes }\end{array}$ \\
\hline 2 & P30041 & Peroxiredoxin-6 & PRDX6 & PRDX6 & 6,02 & 24888 & 1,00 & 0,25 & 0,00 & 0,00 & cytoplasm & cell redox homeostasis \\
\hline 8 & P12004 & $\begin{array}{l}\text { Proliferating cell } \\
\text { nuclear antigen }\end{array}$ & PCNA & PCNA & 4,57 & 28750 & 1,00 & 1,10 & 2,59 & 2,97 & nucleus & cell proliferation \\
\hline 13 & P07355 & Annexin A2 & p36 & ANXA2 & 7,56 & 38449 & 1,00 & 2,58 & 0,00 & 0,00 & secreted & $\begin{array}{l}\text { skeletal system } \\
\text { development }\end{array}$ \\
\hline 20 & P05120 & $\begin{array}{l}\text { Plasminogen } \\
\text { activator inhibitor } 2\end{array}$ & PAI-2 & SERPINB2 & 5,46 & 46566 & 1,00 & 2,18 & 1,84 & 1,50 & $\begin{array}{l}\text { cytoplasm, } \\
\text { secreted }\end{array}$ & anti-apoptosis \\
\hline 32 & Q12931 & $\begin{array}{l}\text { Heat shock protein } \\
75 \mathrm{kDa} \text {, } \\
\text { mitochondrial }\end{array}$ & TRAP-1 & TRAP1 & 8,3 & 80060 & 1,00 & 1,36 & 3,16 & 2,15 & mitochondrial & $\begin{array}{l}\text { cellular response to } \\
\text { oxidative stress and protein } \\
\text { folding }\end{array}$ \\
\hline \multirow[t]{2}{*}{35} & P08238 & $\begin{array}{l}\text { Heat shock protein } \\
\text { HSP 90-beta }\end{array}$ & HSP90 & HSP90AB1 & 4,97 & 83081 & & & & & cytoplasm & protein folding \\
\hline & P07900 & $\begin{array}{l}\text { Heat shock protein } \\
\text { HSP 90-alpha }\end{array}$ & HSP86 & HSP90AA1 & 4,94 & 84490 & & & & & cytoplasm & $\begin{array}{l}\text { mitochondrial transport } \\
\text { and protein refolding }\end{array}$ \\
\hline 38 & P08729 & $\begin{array}{l}\text { Keratin, type II } \\
\text { cytoskeletal } 7\end{array}$ & CK-7 & KRT7 & 5,23 & 51418 & 1,00 & 0,96 & 0,00 & 0,00 & $\begin{array}{l}\text { cytoplasm, } \\
\text { cytoskeleton }\end{array}$ & cytoskeleton organization \\
\hline
\end{tabular}

Shown are SwissProt ID, protein name and abbreviation as well as gene, isoelectric point (pl), molecular weight (MW), regulation, subcellular localization, and a selection of the biological processes the proteins are involved.

by the genetic background and tissue origin of the cells. Nevertheless, PRDX6 is involved in the redox regulation of the cell and may play a role in the regulation of phospholipid turnover as well as in protection against oxidative injury [41]. Changes in redox regulation and pathways appear to be important for tumorigenesis [42] so that the role of PRDX6 during tumorigenesis should to be further investigated.

PAI-2 is well documented as an inhibitor of the urokinase-type plasminogen activator [43]. Furthermore, PAI-2

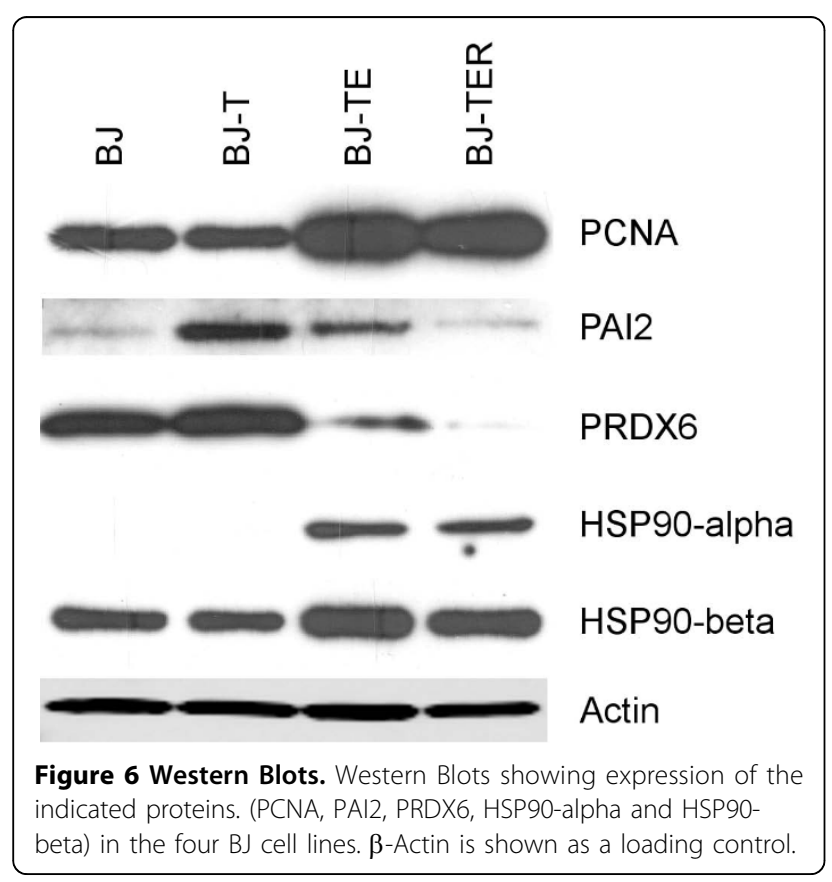

has been shown to carry out a number of intracellular functions: it can alter gene expression, influence the rate of cell proliferation and differentiation, and inhibit apoptosis independent of urokinase inhibition [44]. The crucial change caused by the hTERT transition is yet unclear, but recent findings suggest that the urokinase plasminogen activator system is causally involved at multiple steps in cancer progression [45]. Interestingly, the nuclear-located PAI-2 was shown to bind to RB via its CD-loop [46].

Also, TRAP-1 was reported to interact with RB [47]. TRAP-1 is a chaperone that expresses an ATPase activity and protects cells from apoptosis by an unknown mechanism. Possibly, in tumor cells, the up-regulation of both TRAP-1 in conjunction with HSP90, which both interact with Cyclophilin-40 (CypD) maintains mitochondrial homeostasis and survival of cells. Blocking the interaction of TRAP-1 and HSP90 with CypD leads to CypD mediated mitochondrial induced cell death [48]. In addition, Kang et al. found no increase in TRAP-1 as a result of Ras-transformation. We could support this finding, because TRAP-1 is already up-regulated by means of SV40 ER expression (Figure 7). However, Kang et al. showed HSP90 up-regulation due to Rastransformation; this could also be reinforced by our 2DPAGE findings: We identified the homologous proteins HSP90-alpha and HSP90-beta, sharing 87\% identity to each other in spot 35 . Western Blot analysis indicates up-regulation of both HSP90-alpha and HSP90-beta by SV40 ER. Taken together these results suggest that not only Ras-transformation but also SV40 ER affects HSP90 levels. 


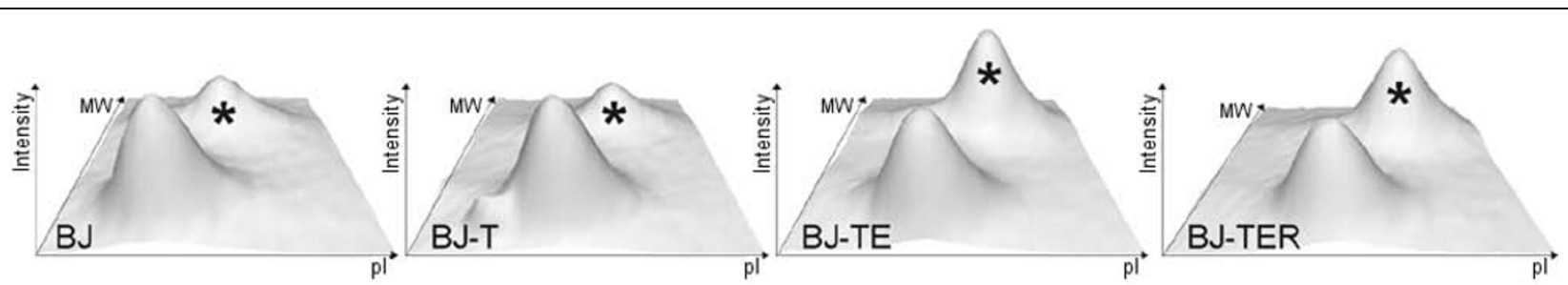

Figure 7 3D view of a gel section from all cell lines: TRAP-1 (spot 32) is identified in the spot marked with an asterisk. Representative single gel sections are selected, that is, those sections closest to the mean of all five gels from one cell line.

HSP90 is a molecular chaperon that has ATPase activity. Its client proteins and interaction partners are several kinases and signaling molecules e.g. Akt, p53 and Hypoxia-inducible factor 1 alpha. HSP90 occupies a unique nodal role in cellular homeostasis, overseeing cell proliferation and cell-survival mechanisms $[48,49]$.

Surprisingly, HSP90-alpha and HSP90-beta as well as PCNA were recently identified as binding partners of p16INK4a [50], suggesting that p16INK4a possibly plays a central role in several steps of tumorigenesis distinct from kinase inhibition. Moreover, the same study also reveals several cytoskeletal proteins as interacting partners of p16INK4a. Some cytoskeletal proteins were identified within our investigation, especially six in the transition from BJ-T to BJ-TE. Considering the profound changes in cell morphology in this step, reorganization of the cytoskeleton appears to be of high importance. Furthermore, among the seven unequivocally identified proteins the cytoskeletal protein CK-7 and the possibly cytoskeleton-associated protein p36 are listed. p36 may cross-link plasma membrane phospholipids with actin and the cytoskeleton and might be involved in exocytosis [51]. Both, p36 and CK-7, protein spots are regulated in the same manner and are absent after expression of SV40 ER. In contrast, CK-7 is described to be up-regulated in several cancers and tumors e.g. breast cancer [52], transitional cell papillomas and carcinomas [53].

Besides these seven unambiguously identified proteins, mass spectrometric analysis identified further potentially regulated proteins. Although these proteins need to be validated in future experiments, our findings point to intriguing interactions between the p16-RB pathway, the mitochondrial chaperone network and the cytoskeleton. In detail, SV40 LT is known to bind RB and inactivate the cell cycle inhibitor $\mathrm{p} 16-\mathrm{RB}$ pathway resulting in increased cell proliferation. In addition, SV40 LT also caused marked changes in cell morphology and rendered the cells more stress-resistant (data not shown). Interestingly, we observed an up-regulation of HSP90 and the RB-interacting protein TRAP-1 (HSP75), which are part of the same mitochondrial chaperone network. Specific expression of these chaperones in mitochondria of tumor cells but not normal cells has been linked to tumor cell survival by their inhibitory effect on the mitochondrial permeability transition [48]. While expression of TRAP-1 was stimulated in response to SV40 early region, mitochondrial HSP90 was induced by oncogenic Ras [48]. Up-regulation of TRAP-1 and HSP90 is therefore directly linked to defined genetic alterations and supports a model of oncogene cooperation in the establishment of this tumor-survival promoting chaperone network. Furthermore, HSP90 has also been identified together with cytoskeletal proteins in immunoprecipitates of the cell cycle inhibitor p16INK4a suggesting a possible link between HSP90 up-regulation and the changes in cytoskeleton dynamics of Ras-transformed cells [50]. The proteomic changes detected in this study therefore provide further insight into the molecular basis underlying malignant transformation. The presented list of proteins enables a more detailed analysis of specific proteins and pathways involved in cancer development. In addition, the list allows the investigation of other cell lines and even different types of cancer concerning the abundance of these proteins. We will therefore further investigate this model system.

\section{Additional material}

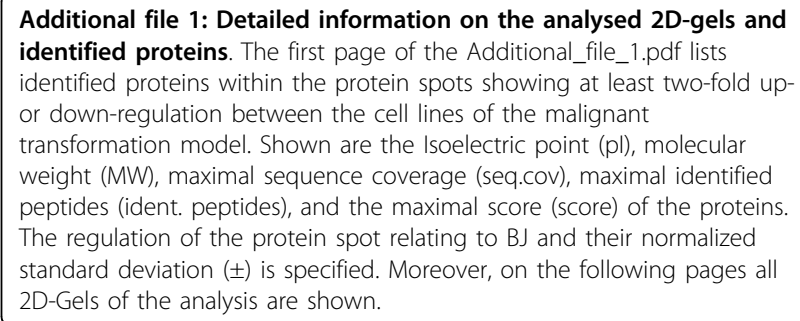

\section{Abbreviations}

Akt: Protein kinase B; CK-7: cytokeratin-7; CypD: Cyclophilin-40; DNA: Deoxyribonucleic acid; DTT: Dithiothreitol; ESI: electrospray ionization; GO: Gene Ontology; HSP: heat shock protein; hTERT: catalytic subunit of the telomerase holoenzyme (Telomerase reverse transcriptase); IEF: isoelectric focusing; IPG: immobilized pH gradient; IPI: international protein index; ITRAQ: isobaric tag for relative and absolute quantitation; LC: liquid chromatography; LT: large tumor antigen; MALDI: matrix-assisted laser 
desorption/ionization; MEFs: mouse embryonic fibroblasts; MS: mass spectrometry; MS/MS: tandem mass spectrometry; MW: molecular weight; p16INK4a: Cyclin-dependent kinase inhibitor 2A; p36: Annexin A2; p53: Tumor suppressor p53; PAGE: polyacrylamide gelelectrophorese; 2D-PAGE: two-dimensional PAGE; PAI-2: Plasminogen activator inhibitor 2; PBS: phosphate buffered saline; PCNA: proliferating cell nuclear antigen; pl: isoelectric point; PP2A: Serin/threonine-protein phosphatase; PRDX6: Peroxiredoxin-6; RB: Retinoblastoma protein; RuBPS: Ruthenium(II)trisbathophenanthroline disulfonate; ST: small tumor antigen; SV40: simian virus 40; SV40 ER: simian virus 40 early region; TRAP-1: mitochondrial heat shock protein $75 \mathrm{kDa}$.

\section{Acknowledgements}

The authors acknowledge the work of Lars Hofmann who generated the cell lines for this study as well as Urs Lewandrowski, Rene Zahedi and Christiane Winkler for their support in LC-MS measurements. SP wants to thank Thomas Raabe for his support. AS thanks the "Ministerium für Innovation, Wissenschaft, Forschung und Technologie des Landes Nordrhein-Westfalen" and the "Bundesministerium für Bildung und Forschung" for continuous financial support. This work was mainly funded by Deutsche Forschungsgemeinschaft (Forschungszentrum FZT-82 and TR17 "Rasdependent pathways in human cancer" project B2).

\section{Author details}

${ }^{1}$ Rudolf Virchow Center, DFG Research Center for Experimental Biomedicine, University of Würzburg, (Protein Mass Spectrometry and Functional Proteomics), D-97078 Würzburg, Germany. ${ }^{2}$ Institute of Medical Radiation and Cell Research (MSZ), University of Würzburg, D-97078 Würzburg, Germany. ${ }^{3}$ Molecular Oncology, Philipps-University Marburg, D-35032 Marburg, Germany. ${ }^{4}$ Leibniz-Institut für Analytische Wissenschaften - ISAS - e. V., D-44227 Dortmund, Germany.

\section{Authors' contributions}

SP made conception of the study, carried out acquisition, analysis and interpretation of data and wrote the manuscript. FV made the Western Blot experiments. TS provided the cell lines. TS and AS participated in the design of the study and contributed to the manuscript. All authors read and approved the final manuscript.

\section{Competing interests}

The authors declare that they have no competing interests.

Received: 26 March 2010 Accepted: 22 September 2010 Published: 22 September 2010

\section{References}

1. Van Dyke T, Jacks T: Cancer modeling in the modern era: progress and challenges. Cell 2002, 108:135-144.

2. Rangarajan A, Weinberg RA: Opinion: Comparative biology of mouse versus human cells: modelling human cancer in mice. Nat Rev Cancer 2003, 3:952-959.

3. Bodnar AG, Ouellette M, Frolkis M, Holt SE, Chiu CP, Morin GB, Harley CB, Shay JW, Lichtsteiner S, Wright WE: Extension of life-span by introduction of telomerase into normal human cells. Science 1998, 279:349-352.

4. Kim NW, Piatyszek MA, Prowse KR, Harley CB, West MD, Ho PL, Coviello GM, Wright WE, Weinrich SL, Shay JW: Specific association of human telomerase activity with immortal cells and cancer. Science 1994, 266:2011-2015.

5. Hahn WC, Counter CM, Lundberg AS, Beijersbergen RL, Brooks MW, Weinberg RA: Creation of human tumour cells with defined genetic elements. Nature 1999, 400:464-468.

6. Elenbaas B, Spirio L, Koerner F, Fleming MD, Zimonjic DB, Donaher $\mathrm{J}$, Popescu NC, Hahn WC, Weinberg RA: Human breast cancer cells generated by oncogenic transformation of primary mammary epithelial cells. Genes Dev 2001, 15:50-65.

7. Lundberg AS, Randell SH, Stewart SA, Elenbaas B, Hartwell KA, Brooks MW, Fleming MD, Olsen JC, Miller SW, Weinberg RA, Hahn WC: Immortalization and transformation of primary human airway epithelial cells by gene transfer. Oncogene 2002, 21:4577-4586.

8. MacKenzie KL, Franco S, Naiyer AJ, May C, Sadelain M, Rafii S, Moore MA: Multiple stages of malignant transformation of human endothelial cells modelled by co-expression of telomerase reverse transcriptase, SV40 T antigen and oncogenic N-ras. Oncogene 2002, 21:4200-4211.

9. Rich JN, Guo C, McLendon RE, Bigner DD, Wang XF, Counter CM: A genetically tractable model of human glioma formation. Cancer Res 2001, 61:3556-3560.

10. Yu J, Boyapati A, Rundell K: Critical role for SV40 small-t antigen in human cell transformation. Virology 2001, 290:192-198.

11. Hahn WC, Dessain SK, Brooks MW, King JE, Elenbaas B, Sabatini DM, DeCaprio JA, Weinberg RA: Enumeration of the simian virus 40 early region elements necessary for human cell transformation. Mol Cell Biol 2002, 22:2111-2123.

12. Voorhoeve PM, Agami R: The tumor-suppressive functions of the human INK4A locus. Cancer Cell 2003, 4:311-319.

13. Yeh E, Cunningham M, Arnold H, Chasse D, Monteith T, Ivaldi G, Hahn WC, Stukenberg PT, Shenolikar S, Uchida T, Counter CM, Nevins JR, Means AR, Sears R: A signalling pathway controlling c-Myc degradation that impacts oncogenic transformation of human cells. Nat Cell Biol 2004, 6:308-318.

14. Rodriguez-Viciana P, Collins C, Fried M: Polyoma and SV40 proteins differentially regulate PP2A to activate distinct cellular signaling pathways involved in growth control. Proc Natl Acad Sci USA 2006, 103:19290-19295.

15. Sontag E, Fedorov S, Kamibayashi C, Robbins D, Cobb M, Mumby M: The interaction of SV40 small tumor antigen with protein phosphatase $2 \mathrm{~A}$ stimulates the map kinase pathway and induces cell proliferation. Cell 1993, 75:887-897.

16. Beitzinger M, Hofmann L, Oswald C, Beinoraviciute-Kellner R, Sauer M, Griesmann H, Bretz AC, Burek C, Rosenwald A, Stiewe T: p73 poses a barrier to malignant transformation by limiting anchorage-independent growth. Embo J 2008, 27:792-803.

17. Görg A, Weiss W, Dunn MJ: Current two-dimensional electrophoresis technology for proteomics. Proteomics 2004, 4:3665-3685.

18. O'Farrell PH: High resolution two-dimensional electrophoresis of proteins. J Biol Chem 1975, 250:4007-4021.

19. Klose J: Protein mapping by combined isoelectric focusing and electrophoresis of mouse tissues. A novel approach to testing for induced point mutations in mammals. Humangenetik 1975, 26:231-243.

20. Sonoda Y, Ozawa T, Hirose Y, Aldape KD, McMahon M, Berger MS Pieper RO: Formation of intracranial tumors by genetically modified human astrocytes defines four pathways critical in the development of human anaplastic astrocytoma. Cancer Res 2001, 61:4956-4960.

21. Serrano M, Lin AW, McCurrach ME, Beach D, Lowe SW: Oncogenic ras provokes premature cell senescence associated with accumulation of p53 and p16INK4a. Cell 1997, 88:593-602.

22. Dieckmann-Schuppert A, Schnittler $\mathrm{HJ}$ : A simple assay for quantification of protein in tissue sections, cell cultures, and cell homogenates, and of protein immobilized on solid surfaces. Cell Tissue Res 1997, 288:119-126.

23. Lamanda A, Zahn A, Roder D, Langen H: Improved Ruthenium II tris (bathophenantroline disulfonate) staining and destaining protocol for a better signal-to-background ratio and improved baseline resolution. Proteomics 2004, 4:599-608

24. Moebius J, Denker K, Sickmann A: Ruthenium (II) tris-bathophenanthroline disulfonate is well suitable for Tris-Glycine PAGE but not for Bis-Tris gels. Proteomics 2007, 7:524-527.

25. Sickmann A, Dormeyer W, Wortelkamp S, Woitalla D, Kuhn W, Meyer HE: Towards a high resolution separation of human cerebrospinal fluid. Journal of Chromatography B 2002, 771:167-196.

26. Eisen MB, Spellman PT, Brown PO, Botstein D: Cluster analysis and display of genome-wide expression patterns. Proc Natl Acad Sci USA 1998, 95:14863-14868.

27. Braun RJ, Kinkl N, Beer M, Ueffing M: Two-dimensional electrophoresis of membrane proteins. Anal Bioanal Chem 2007, 389:1033-1045.

28. Westermeier $\mathrm{R}$, Marouga R: Protein detection methods in proteomics research. Biosci Rep 2005, 25:19-32.

29. Richert S, Luche S, Chevallet M, Van Dorsselaer A, Leize-Wagner E, Rabilloud $\mathrm{T}$ : About the mechanism of interference of silver staining with peptide mass spectrometry. Proteomics 2004, 4:909-916.

30. Winkler C, Denker K, Wortelkamp S, Sickmann A: Silver- and Coomassiestaining protocols: detection limits and compatibility with ESI MS. Electrophoresis 2007, 28:2095-2099. 
31. Rabilloud T, Strub JM, Luche S, van Dorsselaer A, Lunardi J: A comparison between Sypro Ruby and ruthenium II tris (bathophenanthroline disulfonate) as fluorescent stains for protein detection in gels. Proteomics 2001, 1:699-704.

32. Young T, Mei F, Liu J, Bast RC, Kurosky A, Cheng X: Proteomics analysis of $\mathrm{H}$-RAS-mediated oncogenic transformation in a genetically defined human ovarian cancer model. Oncogene 2005, 24:6174-6184

33. Chen WQ, Kang SU, Lubec G: Protein profiling by the combination of two independent mass spectrometry techniques. Nat Protoc 2006, 1:1446-1452

34. Lottspeich F, Engels JW: Bioanalytik München: Spektrum, 22006.

35. Ahuja D, Saenz-Robles MT, Pipas JM: SV40 large T antigen targets multiple cellular pathways to elicit cellular transformation. Oncogene 2005, 24:7729-7745

36. MacKenzie KL, Franco S, May C, Sadelain M, Moore MA: Mass cultured human fibroblasts overexpressing hTERT encounter a growth crisis following an extended period of proliferation. Exp Cell Res 2000, 259:336-350.

37. Zhu J, Wang H, Bishop JM, Blackburn EH: Telomerase extends the lifespan of virus-transformed human cells without net telomere lengthening. Proc Natl Acad Sci USA 1999, 96:3723-3728.

38. MacKenzie KL, Franco S, Naiyer AJ, May C, Sadelain M, Rafii S, Moore MA: Multiple stages of malignant transformation of human endothelial cells modelled by co-expression of telomerase reverse transcriptase, SV40 T antigen and oncogenic N-ras. Oncogene 2002, 21:4200-4211.

39. Chang XZ, Li DQ, Hou YF, Wu J, Lu JS, Di GH, Jin W, Ou ZL, Shen ZZ, Shao ZM: Identification of the functional role of peroxiredoxin 6 in the progression of breast cancer. Breast Cancer Res 2007, 9:R76.

40. Fujita $Y$, Nakanishi T, Hiramatsu M, Mabuchi H, Miyamoto $Y$, Miyamoto A, Shimizu A, Tanigawa N: Proteomics-based approach identifying autoantibody against peroxiredoxin $\mathrm{VI}$ as a novel serum marker in esophageal squamous cell carcinoma. Clin Cancer Res 2006, 12:6415-6420.

41. Manevich $Y$, Fisher AB: Peroxiredoxin 6, a 1-Cys peroxiredoxin, functions in antioxidant defense and lung phospholipid metabolism. Free Radic Biol Med 2005, 38:1422-1432.

42. Noble M, Mayer-Proschel M, Proschel C: Redox regulation of precursor cell function: insights and paradoxes. Antioxid Redox Signal 2005, 7:1456-1467.

43. Kruithof EK, Baker MS, Bunn CL: Biological and clinical aspects of plasminogen activator inhibitor type 2. Blood 1995, 86:4007-4024.

44. Medcalf RL, Stasinopoulos SJ: The undecided serpin. The ins and outs of plasminogen activator inhibitor type 2. Febs J 2005, 272:4858-4867.

45. Duffy MJ: The urokinase plasminogen activator system: role in malignancy. Curr Pharm Des 2004, 10:39-49.

46. Darnell GA, Antalis TM, Johnstone RW, Stringer BW, Ogbourne SM, Harrich $D$, Suhrbier A: Inhibition of retinoblastoma protein degradation by interaction with the serpin plasminogen activator inhibitor 2 via a novel consensus motif. Mol Cell Biol 2003, 23:6520-6532.

47. Chen CF, Chen Y, Dai K, Chen PL, Riley DJ, Lee WH: A new member of the hsp90 family of molecular chaperones interacts with the retinoblastoma protein during mitosis and after heat shock. Mol Cell Biol 1996, 16:4691-4699.

48. Kang BH, Plescia J, Dohi T, Rosa J, Doxsey SJ, Altieri DC: Regulation of tumor cell mitochondrial homeostasis by an organelle-specific Hsp90 chaperone network. Cell 2007, 131:257-270.

49. Isaacs JS, Xu W, Neckers L: Heat shock protein 90 as a molecular target for cancer therapeutics. Cancer Cell 2003, 3:213-217.

50. Souza-Rodrigues E, Estanyol JM, Friedrich-Heineken E, Olmedo E, Vera J, Canela N, Brun S, Agell N, Hubscher U, Bachs O, Jaumot M: Proteomic analysis of p16(ink4a)-binding proteins. Proteomics 2007, 7:4102-4111.

51. Hayes MJ, Merrifield CJ, Shao D, Ayala-Sanmartin J, Schorey CD, Levine TP, Proust J, Curran J, Bailly M, Moss SE: Annexin 2 binding to phosphatidylinositol 4,5-bisphosphate on endocytic vesicles is regulated by the stress response pathway. J Biol Chem 2004, 279:14157-14164.

52. Roberts K, Bhatia K, Stanton P, Lord R: Proteomic analysis of selected prognostic factors of breast cancer. Proteomics 2004, 4:784-792.

53. Ramos-Vara JA, Miller MA, Boucher M, Roudabush A, Johnson GC: Immunohistochemical detection of uroplakin III, cytokeratin 7, and cytokeratin 20 in canine urothelial tumors. Vet Pathol 2003, 40:55-62. doi:10.1186/1476-4598-9-254

Cite this article as: Pütz et al:: Malignant transformation in a defined genetic background: proteome changes displayed by 2D-PAGE.

Molecular Cancer 2010 9:254.

\section{Submit your next manuscript to BioMed Central and take full advantage of:}

- Convenient online submission

- Thorough peer review

- No space constraints or color figure charges

- Immediate publication on acceptance

- Inclusion in PubMed, CAS, Scopus and Google Scholar

- Research which is freely available for redistribution

Submit your manuscript at www.biomedcentral.com/submit
Biomed Central 